\title{
BLACK NEWSPAPERS, REAL PROPERTY, AND MOBILITY IN MEMPHIS AFTER EMANCIPATION
}

\author{
Cara Caddoo
}

"I am an exile from home," Ida B. Wells wrote in the summer of 1892. Shaken but unwavering in her resolve, she recorded the reasons she could not return to Memphis. Her words would not bring back Thomas Moss, Will Stewart, or Calvin McDowell, murdered by a white mob in May; nor could they rebuild the offices of her newspaper, the Free Speech, destroyed just days earlier. Those losses were irrevocable. Yet Wells explained, "I felt that I owed it to myself and to my race to tell the whole truth."' The New York Age published her story on 25 June 1892. Seven columns long, and printed on the cover of one of the nation's most widely distributed black newspapers, her article detailed the "names, dates, and places" of the Memphis lynchings and other murders across the United States (see fig. 1). ${ }^{2}$

Wells would never again call Memphis home. Armed guards patrolled the train station for any sign of her return, and white vigilantes promised to kill her on sight. But she continued to write. In the pages of the black press, she beseeched her readers to migrate. The only option left was to "leave a town which will neither protect our lives and property." In the wake of the violence, more than six thousand African Americans fled Memphis. They ignored the local white newspaper, the Democrats' Argus, which warned of the hardships they would face in Oklahoma, and headed west in search of "some place in our great democracy where their lives, liberty, and property would be protected." Those who could not afford train fare packed their belongings into wagons or set off by foot. ${ }^{3}$

The offices of the Free Speech, the newspaper articles, and the exodus from Memphis illustrate the entwined role of property, mass media, and mobility in the history of black place-making. ${ }^{4}$ This essay examines the tactics Memphis's post-emancipation black population used to generate a shared conception of place in the city and beyond. Multiple factors combined to foster African Americans' collective sense of belonging and set of associations with certain localities. They responded to local segregation laws and access to employment, education, and housing, as well as common desires to escape violence, seek refuge, exchange information, purchase goods, and play.

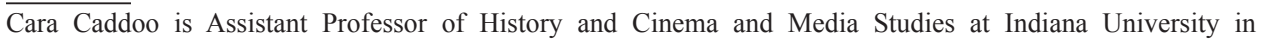
Bloomington. 


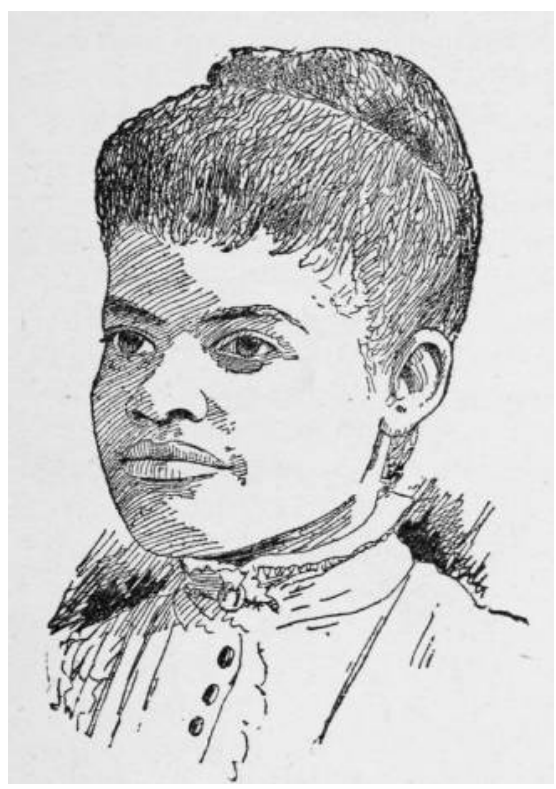

Figure 1: Miss Ida B. Wells.

In Memphis, as elsewhere, real property and mass media were not only co-constitutive but also fundamental aspects of African Americans' efforts to stake claim to the locations they viewed as their own. The destruction of the Free Speech offices and whites' efforts to prevent its circulation, combined with murderous violence, undermined African Americans' sense of where they belonged. Yet the appearance of the New York Age in Memphis only weeks after the attack sheds light on a second important feature of black place-making. By investing in remotely located mass media infrastructures, African Americans forged mechanisms that enabled them to regenerate their collective claim to geographic space in the wake of violence and dispersal. Both the attempts to reclaim black Memphis and the resettlement movement to Oklahoma were engendered by a kinetic conception of place that accounted for the contingencies of modern black life. ${ }^{5}$

Mobility is central to this history. Ida B. Wells, J. L. Fleming, co-owner of the Free Speech, and the lives of countless black migrants are histories of people in motion. Historians have long described mobility as a defining feature of the modern black experience. ${ }^{6}$ From the Middle Passage, to the Great Migration and the carceral state of the present day, the mobility (and immobility) of black bodies has been inseparable from the conditions that have undermined their social and political status. As historian Thomas Holt has written, "slave and post emancipation regimes were contingent on, even dependent on, keeping blacks and other 
racialized groups physically in their place." ${ }^{\prime 7}$ In the late 19th century, migration was paradoxically both a weapon used against African Americans and one of the few tools they had to pursue their aspirations for freedom. As historian Alexander $\mathrm{X}$. Bryd has written, we cannot simply categorize black mobility as either "free" or "forced." Yet systems of racial inequality relied not only on efforts to control the movement of black people, they also required control over the mobility of information across geographic space. For this reason, African Americans have long prioritized the creation of public spaces where they could exchange information and participate in the formation of public opinion. As foundational aspects of freedom and prerequisites for democratic participation, such sites stood at the center of black efforts to forge a place for themselves in the landscape of turn-of-the20th-century United States.

\section{NEW AFRICA}

Memphis once stood as a beacon of hope for thousands of newly freed African Americans. After Union forces captured the city on 6 June 1862, the presence of religious aid organizations and Fort Pickering on the southern bluffs of the Mississippi River, drew thousands of formerly enslaved people from the Delta. In 1863, Harriet Grant made the 200-mile journey from Milliken's Bend, Louisiana, to Memphis with three children: eleven-year-old Henry, six-year-old Abraham, and five-month-old Jacob. ${ }^{9}$ Robert Church, a twenty-three-year-old riverboat steward, arrived in the city in 1862 after federal troops captured the steamer on which he worked. Before the war, there were approximately four thousand free and enslaved African Americans in Memphis; by 1865, the black population had quadrupled to 16,509. At first, the Union Army discouraged the flood of refugees, but federal policies regarding runaway "contraband" changed course in the spring of 1863 . At the southern periphery of the city, the Union established three refugee camps, Shiloh, Fiske, and Camp Dixie, which soon were filled with tents and makeshift schools. Under brush arbor churches, freedman Africa Bailey led prayer meetings for the city's longtime residents and refugees. Morris Henderson, formerly enslaved carriage driver from Virginia, ministered in the borrowed quarters of a white church on Beale Street. ${ }^{10}$ Bluff City's population ebbed and flowed over the next century, but the proportion of black residents would remain among the highest in the United States. ${ }^{11}$

Local whites regarded "New Africa" with disdain. They looked at the sick and starving survivors of slavery and saw idle vagrants and viewed the celebrations of emancipation as scenes of insubordination and indolence. ${ }^{12}$ Confederate sympathizers were especially fearful of the unchecked movement of African Americans in the city, which they blamed for an array of real and imagined social ills, 
from the spread of disease to "miscegenation." Every black person in Memphis was required to register with the Provost Marshal of the district, and unauthorized "assemblages of [N] egroes" were prohibited. ${ }^{13}$ Still, conservative whites believed these policies were too lax. ${ }^{14}$ John McLeod Keating, editor of the Argus, claimed the freedpeople were "running wild," and that drunken black soldiers roved the streets in search of white women to attack. ${ }^{15}$ After the war, tensions between Memphis' black and white residents continued to erupt over the use of urban space. Confederate sympathizer Elizabeth Avery Meriweather recorded the humiliation she felt when a black soldier forced her to step off the sidewalk so that he could pass. "We's all ekal now. Git out o' our way, white woman," she wrote in a caricatured version of his statement. By portraying him as uneducated, she intended to cast him as unfit for citizenship and its attendant rights to public space. Later, Meriweather seethed when Union soldiers allowed a group of black squatters to reside on an abandoned property that she deemed her own. "Any stranger seeing those Negroes would have supposed the blacks not whites were masters in the South," she bitterly remarked. ${ }^{16}$

Meriweather's account illustrates the sense of racialized privilege that conservative whites mapped onto the geography of Memphis, but it also suggests the significance African Americans assigned to urban space. In the black soldier's supposed command to Meriweather, he linked "equality" to the right to freely traverse the city and occupy the same public spaces as whites. After the war, white redeemers continued to thwart black claims to the geography of Memphis. They reinstituted codes that limited black access to, and movement within, the city. ${ }^{17}$ Local courts endorsed, or altogether mandated, racial segregation in public accommodations, which included privately owned hotels, restaurants, and theatres. In 1875, more than two decades before Plessy v. Ferguson, Tennessee state law determined that owners of public accommodations could limit access to their properties just as "any private person over his private house." African Americans were also excluded from publicly owned properties such as parks, playgrounds, sidewalks, and squares. ${ }^{18}$

African American migrants responded by making brick and mortar investments in the city. By 1866, Memphis's black population owned several saloons and barbershops, eight shops, two furniture stores, four lunchrooms, and numerous homes. ${ }^{19}$ Robert Church, among the most enterprising of these individuals, left his trade as a riverboat steward and opened a saloon on 29 Monroe Street, near Fort Pickering. ${ }^{20}$ Church's business made material and representative claims to the landscape of Memphis. The location and proximity of such properties contributed to African Americans' efforts to designate their shared place in the city. Over a cigar and a glass of whiskey at Church's saloon, black patrons (mostly men) rested their feet and gathered to discuss the latest news. In the Jim Crow city, black 
real properties served a multitude of essential purposes. Without a local hotel that welcomed black patrons, it was difficult to foster business relations or attract touring entertainers. The absence of restaurants or, more urgently, restrooms open to people of color deterred African Americans from particular neighborhoods. Black mobility in the city and the circulation of information of interest to "the race" relied on public spaces that African Americans created for themselves.

Real estate investors like Robert Church understood that property ownership afforded African Americans an exceptional degree of legal rights to urban space. Such claims hinged on ordinances, zoning laws, building codes, and the extent to which courts and the police enforced their transactions and contracts - all racially inscribed factors in turn-of-the-century Memphis. Yet the sanctity of private property in the eyes of the liberal state provided African Americans with their most powerful legal tool in the battles for the geography of Jim Crow America. ${ }^{21}$ The era's veneration of private property dovetailed with the beliefs of middle-class African Americans who viewed economic progress as the key to "uplifting the race." In the Bright Side of Memphis (1908), author and schoolteacher Green P. Hamilton celebrated the properties of local black business and homeowners. For Hamilton, real property and citizenship were inseparable. "[M]an is not considered a substantial citizen, ..." he explained, "unless he owns a part of the soil." 22 Aspirations for property ownership were also informed by longstanding black and white associations of land ownership with ideas of freedom that predated the Civil War. Editors of antebellum black newspapers in the North encouraged their readers to acquire property in order to achieve greater autonomy and to demonstrate they were fit for the responsibilities of citizenship. ${ }^{23}$

Still, the prospect of property ownership was out of reach for most black migrants. Even those with middle-class jobs such as Ida B. Wells could not afford such investments. Indeed, when Wells arrived in Memphis in 1885, she struggled to pay the ten to fifteen dollars in monthly rent at the boardinghouses where she lived. When she was unable to pay her landlord, Mrs. Powell, on time, Wells was forced to hire herself out as a day laborer. "The winter of my discontent is made more so by Mrs. P[owell]'s determination to hire out at the end of the week,"Wells lamented in her diaries. As a school teacher, Wells earned more than most black women who worked full time as domestics and washerwomen, but she could still barely make ends meet. Her experiences bring to relief the uneven privileges to urban space that African American property ownership conferred upon the black residents of Memphis. Black property owners often ruthlessly asserted their authority over their boarders. After Wells left the Powell boardinghouse, she moved into the home of Mrs. Hill, where a young woman named Ella and a teenage boy named Boots also boarded. One night, Wells was horrified to discover that Mrs. Hill had locked Ella outside for hours in the January cold because of a quarrel. 
The next morning, Mrs. Hill beat Ella with a stick, while Boots helplessly tried to defend his "sister." 24

While most African Americans were unable to purchase their own homes and businesses, the vast majority invested in collectively owned black properties. ${ }^{25}$ Such properties provided African Americans the opportunity to create their own public spaces - a prerequisite for claiming one's rights as a free person. White Memphis could peruse books at the Cossitt Library or spend their leisurely Saturdays picnicking at Olympic Park. ${ }^{26}$ But African Americans who desired to occupy taxpayer-funded common properties could only do so by special permission, if at all. African Americans thus financed their own hospitals, orphanages, and libraries, which illustrated black investments in their shared lives and hopes for the future. In Memphis, Africa Bailey and Morris Henderson helped organize an orphanage for black children in $1875 .{ }^{27}$ Donations also enabled African Americans in the city to erect collectively owned fraternal halls, which in turn, rented space to black businesses and hosted theatrical performances and music concerts. The three-floor brick Odd Fellows Hall, located in the heart of Memphis' business section, was celebrated as a "monument to their progressiveness" (see fig. 2).$^{28}$ Likewise, educational facilities such as Howe Institute and LaMoyne Institute were initially founded with funds donated by whites, but relied on the labor and financial contributions of African Americans for their maintenance. ${ }^{29}$

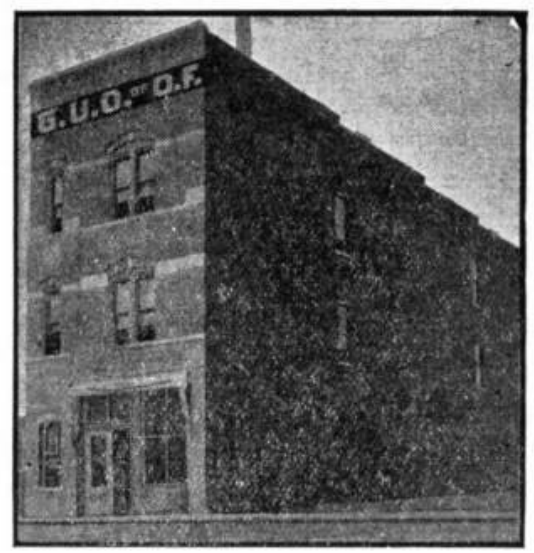

Figure 2: Odd Fellows' Hall, Memphis, TN.

In pennies, nickels, and dimes, Morris Henderson and his congregation collected the funds to pay for the lot where they hoped to build their new church. In 1865 , the women of the congregation had raised $\$ 406.50$ by organizing a church fair - enough for a down payment but far from the $\$ 5,000$ they needed in total. ${ }^{30}$ Each Sunday, members of the church marched to the front of the crude lumber 
shack where they worshipped and piled their coins on a table. ${ }^{31}$ The scale of black investments in collectively owned properties was all the more remarkable when understood in the context of the meager earnings of a largely impoverished population of formerly enslaved working class migrants. ${ }^{32}$ Such endeavors were a striking example of how African Americans' investments in real property altered the post-emancipation built environment. As Baptist minister and longtime president of Morehouse College, Benjamin Mays, once explained, "No other single objective in the history of the Negro group has commanded the degree of financial support from members and non-members like that of church buildings." 33

Church properties, the single largest repositories of black public wealth, stood as the foundation of black claims to city space in the early 20th century. By the 1930 s, African Americans had accumulated $\$ 164.5$ million (or nearly $\$ 2.8$ billion today) in church properties. ${ }^{34}$ They were beacons for resettlement, and more than any other structures, they served as public spaces for turn-of-the-century black life. Churches appeared everywhere African Americans migrated after the war. From Mother Zion and Abyssinian Baptist in Harlem, to Olivet Baptist and Quinn African Methodist Episcopal in Chicago, churches were the first properties to stake blacks' claims in the neighborhoods that African Americans came to view as their own. ${ }^{35}$ Two decades after emancipation, African American churches had a seating capacity of 8 million: a place for every black man, woman, and child in the United States. Lined up side by side, their seats would have reached from the southern tip of the Illinois Central Railroad to Chicago's Union Station and back again. ${ }^{36}$

\section{RIOTING AND RESURRECTION}

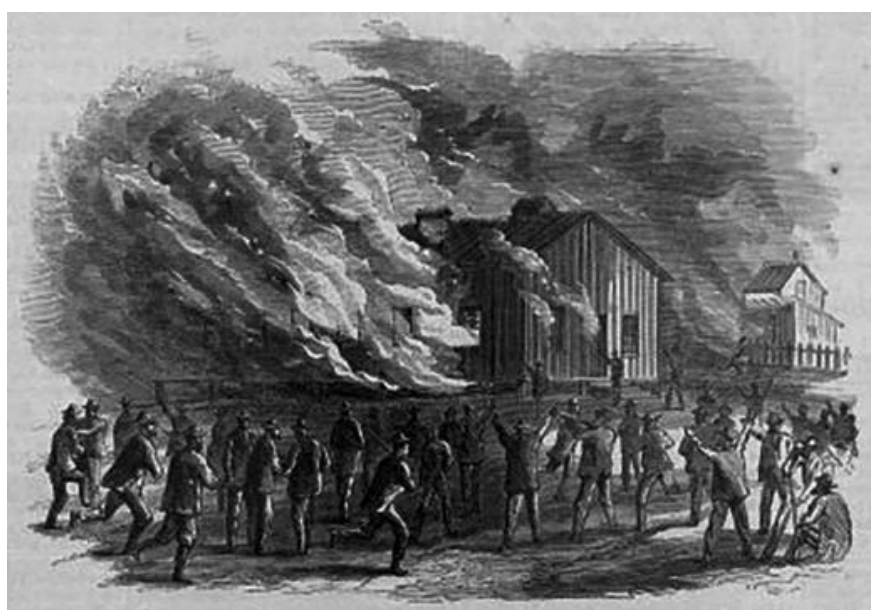

Figure 3: Scenes in Memphis, Tennessee, during the riotburning a school house for the freedpeople. 
In the spring of 1866, conservative whites struck at the very foundations of black life in Memphis. For three days, fires blazed across the city as white mobs, led by the local police force, attacked black residents and their properties. Robert Church recalled, "[A] number of persons jumped on a colored man near my place and abused him very badly." When the man ran into Church's saloon, the mob followed him inside and began to shoot. Church was hit twice, once in the arm and again, in the neck. As he lay bleeding, his attackers drank the whiskey from his bar and stole whatever cash they could find. Church recognized two of the men as police officers Shelby and Roach. ${ }^{37}$

By the end of the rioting, fifty people were dead. At least five black womendisabled Frances Thompson, Rebecca Ann Bloom, Lucy Tibbs, Harriet Armor, and Rachel Hatcher - had been raped. ${ }^{38}$ The mobs destroyed ninety buildings, including all of the black schoolhouses and churches in the city (see fig. 3). ${ }^{39}$ These attacks were not arbitrary. In reference to Reconstruction era sexual violence, historian Hannah Rosen has explained that the rioters were deliberate in their intentions. Acts such as rape were "well-orchestrated" means of re-inscribing antebellum racial hierarchies that erased the rights of black women to their own bodies. ${ }^{40}$ The destruction of black properties, too, intended to reverse the course of emancipation. The destruction of Memphis' black churches, homes, stores, and schools sought to unmake the fruits of citizenship that 19th century Americans connected with property ownership, among them, economic self-sufficiency and the right to civic participation. At the same time, the mobs hoped to thwart the black population's prospects for upward mobility by demolishing the spaces where African Americans collectively mobilized and pursued their goals of racial advancement. The destruction of "every school-house for colored children, and every place of worship for the freedmen" indicated the meticulous and calculated nature of the attacks (see fig. 4). ${ }^{41}$

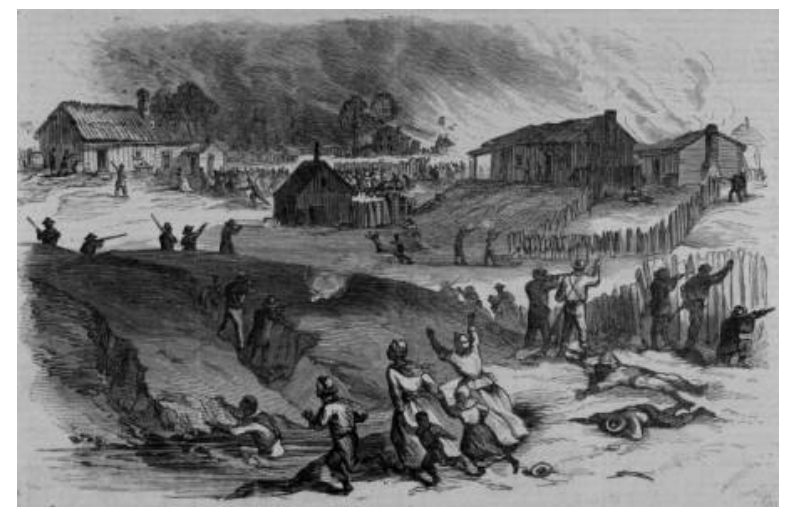

Figure 4: Scenes in Memphis, Tennessee, during the riotshooting down black people on the morning of 2 May 1866. 
After the rioting, Memphis' black population fell by more than a quarter, but those who remained doubled down on their investments in the city's geography. Robert Church, who miraculously survived the attack, eventually rose to become one of the largest landholders in Memphis. Five months after the riots, on 19 October 1866, Morris Henderson arrived at the Freedman's Bank with Charles C. Dickinson and Saul Silliman, fellow members of the Baptist Church's finance committee. Short with a slight build, Henderson was an unassuming figure, but his task that day was monumental. Henderson, who never learned to read or write, painstakingly signed his name in a knotty, curling script, and deposited the last of the $\$ 5,000$ the church needed to acquire its plot of land on Beale Street. ${ }^{42}$ Three years later, the congregation had raised enough money to move into its new building. Chlora Hurse, one of the church's oldest members, recalled the day when the contributions were piled so high on the table that the deacons needed "shovels and buckets to take the money away." ${ }^{33}$ The women who labored for years to fundraise for the building made sure the space would belong to them, too. In the deed for the building, the Sisters of Zion, a mutual aid organization of the church's female members, was promised, "the privilege of using the basement for meetings and transacting their business." ${ }^{44}$ Upon its completion, the Beale Street Baptist Church was celebrated near and far for its "material grandeur and in spiritual influence" 45

Yet the rioting had exposed another truth: the limitations of property ownership in ensuring black claims to Memphis. Like the anchor of a ship, real properties offered support, but no guarantee of security. African Americans could still be set adrift amid the storms of racial violence that frequently washed over the city. The police had not only refused to protect the property rights of men such as Robert Church Sr., they had participated in the looting and arson. Indeed, African Americans were never as fully in possession of their property as their white counterparts. Besides the devastation unleashed by white mobs, African Americans faced discriminatory courts and fewer protections by the state, especially after the federal government retreated from its commitment to reconstructing the former Confederacy. The loss of black properties threatened to erode one of the most fundamental arenas for black place making: the existence of public spaces open to African Americans.

\section{BLACK PRINT CULTURE AND PLACE-MAKING}

In 1871, with the support of the state Baptist Association, Charles C. Dickinson, clerk of the Beale Street Baptist Church and member of its finance committee, published the city's first black newspaper. ${ }^{46}$ The Missionary Baptist was cooperatively owned and printed on Saturdays. During its tenure, it was primarily a semi-monthly, but it briefly ran as a weekly publication. ${ }^{47}$ Appearing shortly after 
conservative whites regained control of the state in 1869, the paper reflected the local black population's growing demand for a public forum of their own. A year after the Missionary Baptist's debut, Alfred Froman, Sr., a close acquaintance of Ida B. Wells, began publication of the Memphis Planet, the city's first secular black newspaper. "Devoted to the best interests of the colored people," the Planet prioritized issues it deemed relevant to African Americans rather than those dictated by political allegiance or religious denomination. Advertisements for the paper, which announced it was "[o]wned and controlled exclusively by colored men," further emphasized the Planet's commitment to racial self-help and the belief that intra-racial endeavors were the key to black progress. ${ }^{48}$

Memphis' expanding black print culture represented a continued recognition of the power of public space and a shift in the local black population's place-making strategies. Clearly, the black press operated differently from brick and mortar structures in asserting black claims to Memphis, but both were invested in ensuring African Americans had public spaces where they could exchange information and form their own opinions. African American residents had long viewed the press as a powerful social and political force. After the riot in 1866, they blamed the city's Democratic newspapers for exacerbating racial tensions. ${ }^{49}$ Such concerns grew more urgent as Republican newspapers folded following the resignation of Tennessee's Governor William G. Brownlow, who had supported the state's Republican papers with printing subsidies. ${ }^{50} \mathrm{~A}$ few conservative African Americans such as Baptist minister Thomas O. Fuller boasted that white newspapers published whatever he wished, even though he admitted, "sometimes I say something they don't care to publish and they cut it out." ${ }^{51}$ More widespread, however, was disillusionment with the white press, typified by the experiences of the city's black religious leaders after the Memphis Commercial Appeal published an incendiary editorial about the "failure" of black suffrage in 1903. Local ministers asked for the opportunity to compose a response, which Commercial Appeal agreed to print. But when Rev. J. H. Grant's editorial appeared in the paper, he noticed his words had been edited in a manner "which changed the meaning of the author and gave it color that was not intended." Rather than depend on the Commercial Appeal to clarify his position, Grant decided to publish his full response in a lengthy pamphlet, which he had printed in a black-owned shop. ${ }^{52}$

Although mass media is often presumed to be detached from geographic space, the development of Memphis's black print culture was profoundly spatial. Transformations of the built environment shaped the emergence of black newspapers across the South. In both their content and the physical locations, Memphis' black newspapers reflected, and responded to, the hardening of Jim Crow segregation, particularly after Memphis's black population lost political power after 1879. The city's earliest black newspapers, the Missionary Baptist and the Memphis Planet, 
shared offices at 227 Second Street with two white newspapers, the Memphis Journal, a German-language newspaper, and the Tennessee Baptist. ${ }^{53}$ Yet as segregation came to infiltrate nearly every aspect of black life in the city, such arrangements presented enormous complications. ${ }^{54}$ White printers who opposed the material they were given could simply refuse to print it. For example, historian Armistead Pride has written about the Georgia Colored Tribune's seven-year hiatus, when all of the city's white printers refused to publish the paper. ${ }^{55}$ In the landscape of Jim Crow America, where African Americans published their newspapers dictated much of what they could publish.

In 1882, Morris Henderson's successor at the Beale Street Baptist Church, Taylor Nightingale, joined Charles Dickinson's Missionary Baptist, which they operated for a year before they sold it to J. T. Turner, a teacher at the Winchester Street Public School. ${ }^{56}$ Turner renamed the paper the Memphis Watchman and moved its offices from 227 Second Street to Beale Street, into the same building as Robert R. Church's famous New Era Tavern. ${ }^{57}$ By the turn of the century, nearly all of Memphis's black publications were consolidated in the city's African American district. Just as Morris Henderson and his congregants moved out of the white-church building on Beale Street into their own property, black newspapers increasingly shifted into spaces of their own. The Living Way was also located on the block, at 161 Beale Street. When mobs attacked the Free Speech's offices, it was located on Hernando Street, just steps away from the other newspapers. By 1908, the black district was dotted with the offices of black publications. The Bluff City News was headquartered at 431 Beale. ${ }^{58}$ At 553 Leath Street were the offices of the Memphis Baptist Herald, edited by Rev. B. R. Bell, which had "a large circulation, both in Memphis and in the state of Mississippi." ${ }^{59}$ The Mid-Weekly Progress, which stood for the "highest moral and intellectual advancement of the race," was edited by James E. Washington at 1179 E. Trigg Street. ${ }^{60}$

Collectively owned, private properties such as the Beale Street Baptist Church fostered the emergence of Memphis's black press. In 1888, the Free Speech and Headlight joined the city's roster of black periodicals. After J. L. Fleming joined the publication, he and Nightingale invited Ida B. Wells to serve as editor, which she agreed to on the condition that she became a partial owner of the paper. ${ }^{61}$ They renamed their joint venture the Free Speech and headquartered it in the basement of the Beale Street Baptist Church. ${ }^{62}$ Post-emancipation black schools and churches provided institutional support and served as the sites where news was delivered, editors met, type was set, ink applied to newsprint, and paper trimmed. In Memphis, Howe Baptist Institute, a black normal and religious school, and LeMoyne Institute, a school for prospective teachers, both had their own printing departments. ${ }^{63}$ The Head and Hand was printed at LeMoyne Institute on South Orleans Street, a block and a half south of Beale Street. ${ }^{64}$ Principal Thomas O. Fuller edited 
the Signal, a "bright and newsy paper" produced by the printing department of Howe Institute and supported by the Baptist denomination of West Tennessee. ${ }^{65}$ Decades later, St. Clair Drake and Horace R. Cayton found that a third of black churches in Chicago possessed mimeographed or printed church newspapers. ${ }^{66}$

"Race newspapers" provided opportunities for black residents of Memphis to connect with each other and with African Americans beyond the city. ${ }^{67}$ Turner expanded the Memphis Watchman into a four-column, eight-page weekly. The paper, "devoted to the interests of the colored race" published local and national news that was reprinted in black newspapers from Harrisburg, Pennsylvania, to Huntsville, Alabama ${ }^{68}$ By 1887, its circulation had grown to 1,200 . When Wells moved to Memphis, her first foray into journalism began after Minister R. N. Countee of Tabernacle Baptist Church attended a lyceum to hear her speak. Impressed, he invited her to write weekly letters for his newspaper, Living Way. ${ }^{69}$ Dedicated to matters of religion and black advancement, it claimed to be "one of the first papers to employ colored men as compositors." ${ }^{\prime 70}$ By 1887 , Living Way claimed a circulation of about a thousand. Soon after Wells joined the paper, other black newspapers across the country, including the Little Rock Sun and the Washington Bee, began re-printing her articles. ${ }^{71}$ Her writing also attracted the attention of T. Thomas Fortune, editor of the New York Freeman, who would later publish Wells' exposé of the Memphis lynching in his newspaper, the New York Age. ${ }^{72}$

Similarly, the black press relied on black properties for distribution of their publications. The locations where African American newspapers could be sold were considerably more circumscribed than those of white papers. Some white shops sold black papers, but often subjected their consumers to the whims and oversight of white vendors. The Free Speech was printed on pink paper to prevent white merchants from tricking illiterate consumers into purchasing white papers. In 1900, more than 44 percent of African Americans in the southern states were illiterate. ${ }^{73}$ African American drugstores, churches, and the lodges of fraternal organizations were important sites where individuals acquired black publications. ${ }^{74}$ The Beale Street Church was not only the first office of the Free Speech and Headlight, it also served as a newsstand for the fledgling publication. On Sundays, Nightingale used his pulpit to strongly encourage Beale Street churchgoers to purchase and read the newspaper. ${ }^{75}$

As Wells attempted to increase the circulation of the Free Speech, she relied on the existence of public spaces where black people could gather and hear her speak about the newspaper. In the Jim Crow city, both private and collectively owned black properties served these purposes. Wells traveled to large cities along the Delta spur of the Illinois Central Railroad. ${ }^{76}$ "Wherever there was a gathering of the people, there I was in the midst of them, to solicit subscribers for the Free Speech and to appoint a correspondent to send us weekly news," she later explained. ${ }^{77}$ In 
Greenville, Mississippi, Wells attended a meeting of the state bar association and left with a subscription from every man in the room. In Water Valley, Mississippi, the state's grand master of the Masonic Lodge suspended the group's meeting for half an hour while she appealed to them for subscriptions. ${ }^{78}$ In less than a year, the circulation of the Free Speech had increased from fifteen hundred to four thousand..$^{79}$

Collectively owned black properties enabled those who could not read or afford to purchase their own newspapers the opportunity to consume black newspapers. Properties such as the Vance Street Christian Church made it possible to "hear" rather than "read" its church paper, The Evening Star. When Wells moved to Memphis in 1883, she attended a lyceum at the church each Friday during which time the editor of the "spicy journal" read it aloud. For the attendees of the lyceum, listening to the "current events, literary notes, poetry, editorials, and a 'They Say' column of pleasant personalities" was a social experience. ${ }^{80}$ The popularity of the weekly Evening Star readings at the church hints both at the ways illiterate residents of Memphis accessed black newspapers, and at the particular pleasures that African Americans received from listening to newspapers together. Likewise, individuals with varied levels of literacy purchased the Free Speech ${ }^{81}$

The prevalence of reports on homes, churches, and other buildings in the black press illustrates a second aspect of the interconnected role of real properties and media in black place making. Newspapers regularly reported on the construction of black-owned properties, religious histories and compendiums, and obsessively listed the values of black church edifices. Biographical entries usually described the value of properties owned by black leaders as illustrations of their achievements. Entire newspapers such as The Cimeter of Muskogee, Oklahoma, were dedicated to town boostersim. I. Garland Penn in The Afro-American Press and Its Editors (1891) included numerous references to the construction of properties in his profiles of newspaper editors, many of whom were also ministers. This was the case with William B. Johnson, editor of the Wayland Alumni Journal, who built a "fine edifice" for the First Baptist Church of Frederick, Maryland. A. N. McEwan, editor of the Baptist Leader, led construction of "one of the finest" church buildings in the South to the tune of over $\$ 50,000$. And Calvin S. Brown "began to issue [a] monthly paper known as The Chowan Pilot, by aid of which, in less than eighteen months, a two-story school-building, 60 by 30, was completed and paid for." ${ }^{82}$ As the rate of black migration accelerated at the turn of the century, newspapers reported on the land- and property-owning opportunities in cities across the pathways of migration from Canada to Mexico.

Visual depictions of properties, second only to portraits of people, were the most commonly featured images in black newspapers, books, and magazines. Scholars have explored how African American men and women used photography 
and other forms of visual self-representation to present black people as respectable, defiant, and worthy of the rights of citizenship. ${ }^{83}$ After emancipation, portraiture became a widespread means for African Americans to assert their claims to freedom in a visual field that had historically used images to mark racial difference and justify the enslavement of black bodies. Through their ubiquitous images of buildings, black publications promoted property ownership as a strategy for self-determination in post-emancipation Memphis and beyond. Such images also served as evidence of black progress and assertions to the rights of citizenship. Illustrations and photographs of homes often correlated material wealth with racial progress, but they served other purposes, too. As beacons and landmarks of black settlements, properties served as evidence of a thriving black community for would-be migrants. ${ }^{84}$ Books such as Hamilton's Bright Side of Memphis featured dozens of images of buildings, from the city's fanciest church edifices, including Mount Olive Colored Methodist Episcopal Church, Collins Chapel, and St. Stephen's Baptist Church. Hamilton's book also featured the impressive residences of the city's leading black citizens such as M. L. Clay, J. T. Settle, and T. S. Brooks. ${ }^{85}$

\section{BLACK NEWSPAPERS AND WHITE VIOLENCE}

Few understood the spatial and material conditions necessary for the publication of black newspapers like J. L. Fleming, Wells's business partner and co-owner of the Free Speech. Before he settled in Memphis, Fleming was editor of the Marion Headlight in Crittenden County, Arkansas. ${ }^{86}$ Fleming migrated to Marion in 1884 with high hopes for the town's black population. When he visited the offices of the New York Freeman in 1886, the paper enthusiastically reported that African Americans in Marion were "doing very well indeed." 87 Under Fleming's editorship, the Headlight earned a national reputation as an upstanding black newspaper. W. Calvin Chase's Washington Bee, a black newspaper known for never holding back its stinging criticisms, applauded Fleming's "untiring efforts" and "powerful and plainspoken" style. The Headlight had "done much good throughout the country," the Bee declared in 1887, not to mention the "the advantages that have accrued to the town of Marion and Crittenden County since the first issues of that paper." 88

The Marion Headlight published its last issue in $1888 .^{89}$ On the morning of 12 July, Fleming was at work when a mob of more than one hundred white men surrounded his building..$^{90}$ Armed with "Winchester rifles," the group forced him and David Ferguson, the black clerk of the circuit court, outside and told them to leave. ${ }^{91}$ The rampage resumed as the mob continued across town. One by one, the group rounded up the black residents it perceived as troublemakers, and marched them to Mound City. Under the guard of three armed men, the prisoners were forced onto 
a ferry and transported to Memphis. Other black residents left Marion soon after spurred by physical force or threats of violence. As Fleming later recalled, the individuals expelled from town lost their homes and their property. Years later, some were still separated from their families. ${ }^{92}$ The threat to their lives was unambiguous. "[T] hey said we were never to come back to that county anymore, and if we did, it would be dangerous," Fleming explained, "they meant . . . they would kill us." 93

Because of the public nature of their work, black newspaper editors like Fleming were frequent targets of attack. Neither newspapers nor real properties could guarantee black claims to the locations they viewed as their own. However, as mutually constitutive but not entirely identical sites of black place-making, one might offer, at times, a mechanism for regenerating the other in the wake of violence. Sometimes this led African Americans to remake their claims to place in the same geographic locations where they had been previously attacked and their properties destroyed. Other times, they collectively transported their shared sense of belonging to new locations. Fleming, for example, did not return to Marion after his home and newspaper were destroyed. Instead, he and other victims of the expulsion settled in Memphis where they attempted to remake a sense of collective belonging. Fleming built on his social and professional networks when he partnered with Taylor Nightingale to form the Free Speech-Headlight. ". "[I]f persecuted and driven from one place, we must set up the printing press in another and continue the great work till the evils we suffer are removed or the people better prepared to fight their own battles," Ida B. Wells explained to the National Press Association in 1893. Still, Wells's energetic call to arms should not obscure the often-Sisyphean task assigned to black newspapers and publishers. The church made possible the resuscitation of Fleming's publication, but considering the violence that led him to Memphis, and the events that later unfolded there, his story was far from triumphant.

The efforts to create a black print culture in Memphis converged with those of black editors, readers, and institutions elsewhere. Contemporaries of Wells and Fleming, such as I. Garland Penn, editor of the Laborer, and author of The Afro-American Press and its Editors, noted a sudden proliferation of black newspapers after 1880. Although Penn's numbers excluded many smaller publications, he identified approximately 10 newspapers in 1870; by 1880, the number had tripled, and by 1890 , he knew of 154 black newspapers in print. ${ }^{95}$ The antebellum period had witnessed the publication of numerous pamphlets and several journals intended for black readerships, including The Appeal, Freedom 's Journal, and Rights. ${ }^{96}$ But it was not until emancipation, or more importantly until the "inward" turn of black life after the end of Reconstruction, that black newspapers proliferated across the South.

African Americans reflected on the role their emergent print culture played in "unifying the race." In his book, Penn ruminated on the changes wrought by the accelerated speed with which African Americans could exchange information and 
form public opinions. William Sanders Scarborough, the future president of Wilberforce University, similarly noted the role of the black press in establishing "a closer bond of union among us" which had "enabled [us] to present a solid front, make a stronger fight for our rights, and thereby demand fair play in the race of life." 97 Scarborough continued by describing black periodicals as "a part of the race - an inseparable part." ${ }^{\prime 98}$ Such opinions were shared broadly. As William H. Johnson, a medical doctor, explained, "The achievements of the Afro-American editor have resulted in the unification of the Afro-American people." 99

The freedpeople drew connections to one another, and to an increasingly broader conception of their shared place across vast distances, through the circulation of an array of newspapers, compendiums, yearbooks, sociological studies, and directories. By publishing everything from the doctrinal statements of black denominations to legal concerns and historical sketches, African American print culture encouraged the African American public to envision itself as cohabitants of an imagined common place. ${ }^{100}$ Richard H. Boyd, founding member of the National Baptist Convention, was an especially enthusiastic contributor to the era's black print culture. He not only wrote several books that promoted the inward reflection of black publications, including the National Baptist Pastor's Guide (1900), The Separate or "Jim Crow" Car Laws (1909), and The Story of the Publishing Board (1920), his books were also published by the National Baptist Publishing Board, an organization that Boyd had begun, and one of the growing number of black book publishers of the era. ${ }^{101}$

On the day that Wells learned of the destruction of the Free Speech, she had just arrived in New Jersey to meet T. Thomas Fortune, editor of the New York Age. She had not yet read the morning papers when Fortune met her at the station and handed her a copy of the New York Sun. Wells read the chilling news of the attacks. Wells recalled, "The article stated that, acting on an editorial of the Commercial Appeal of the previous Monday morning, a committee of leading citizens had gone to the office of the Free Speech that night, run the business manager, J. L. Fleming, out of town, destroyed the type and furnishings of the office, and left a note saying that anyone trying to publish the paper again would be punished with death." 102

Like the 1866 riot, the attack on the Free Speech offices was well orchestrated, aimed at a site that black Memphis had created to defend its rights as citizens. After the murders of Thomas Moss, Will Stewart, and Calvin McDowell in March 1892, Wells began printing public denunciations of the murders. Moss had been killed "because he as a man defended his property from attack." With the help of the Free Speech, her words were "reechoed among our people throughout Memphis." ${ }^{103} \mathrm{Be}-$ sides wanting to silence the incendiary reports about the murders, the mob hoped to reverse the claims to citizenship represented by the newspaper-a medium long associated with democratic participation, which stood as evidence of black literacy and the ability to independently form its own public opinions. 
It was too dangerous for Wells to return to Memphis, but through the pages of the New York Age, she had found another way to reach the city. The sense of place generated through the mutually constitutive role of real property and print culture linked black Memphis to New York City and to distant populations and locations beyond. A thousand copies of the issue of the New York Age featuring her story were sold in Memphis. ${ }^{104}$ Wells could circulate the information to the many papers she wrote for, which included the New York Age; the Detroit, Michigan, Plaindealer; the Indianapolis World; the Gate City Press in Kansas City, Missouri; the Little Rock, Arkansas Sun; and the American Baptist in Louisville, Kentucky. ${ }^{105}$

Wells's ability to transmit information across geographical space speaks to the relative mobility afforded African American women in the era. Her literacy and status as a middle-class woman were both crucial aspects of her persona. Like all places, the practices of black place-making were uneven and influenced by an array of factors such as gender and class. The emphasis on "race" as the unifying factor in the formation of both a print culture and motivation for investments in collectively-owned black properties should be read as a set of historical negotiations rather than evidence of equal access or a homogenous set of opinions - notions often associated with romanticized ideas of, for example, the bourgeois public sphere.

For Fleming, the destruction of the Headlight was an unrecoverable trauma. Twice, he had been forced to flee from his home; twice, his paper was destroyed. He announced he was "through with newspapers." "To lose everything the second time when prospects were so bright was almost more than Mr. Fleming could bear," Wells recalled. In Chicago, friends from Memphis convinced him to restart the paper, but the third iteration of the Free Speech/Headlight was even shorter-lived than the earlier ones. "With no money and little help," Fleming gave up and migrated to Kansas. ${ }^{106}$ Fleming's lack of resources and inability to resuscitate his newspaper were inseparable from the history of violence he had experienced. When the Marion Headlight was destroyed, he had suffered a "smart loss of money," which was only compounded by the attack on the Free Speech in Memphis. ${ }^{107}$ For Wells, too, the loss was financially ruinous. She had invested "every dollar [she] had in the world" in the paper. ${ }^{108}$ As Fleming's experiences demonstrate, the networks between black real properties and media might, at times, offer African Americans the opportunity to regenerate a shared sense of place, but they were not immune to systems of racial oppression and violence.

\section{STAKING CLAIM TO THE PROMISED LAND}

After the lynchings, scores of migrants left Memphis with the hopes of rebuilding their lives in Oklahoma. There, they continued to invest in both properties and mass mediated forms of communication in order to claim their rights as citi- 
zens and make a place for themselves in the post-emancipation world. Solomon Sir Jones, a Baptist minister and businessman, was especially active in these endeavors. By 1913, Jones had erected five churches in the Oklahoma territory, a feat that garnered him national acclaim (see fig. 5). ${ }^{109} \mathrm{He}$ also edited the Baptist Informer, a black weekly in Muskogee, Oklahoma. ${ }^{110}$ Besides the advertisements of town boosters that promised the "best lots" in Muskogee and the "good opportunity" for investment in Glover, Oklahoma Territory, readers of the Informer might learn of the $\$ 45.12$ raised for a new Baptist church in Wagoner, Oklahoma, or about the intention of the Muskogee Baptist Young People's Union (BYPU) to collect past dues for the purpose of constructing new properties. "Let us build churches on the hill, school houses on the plains, erect cottages . . . and thereby have better citizens," the BYPU urged its constituents. ${ }^{111}$

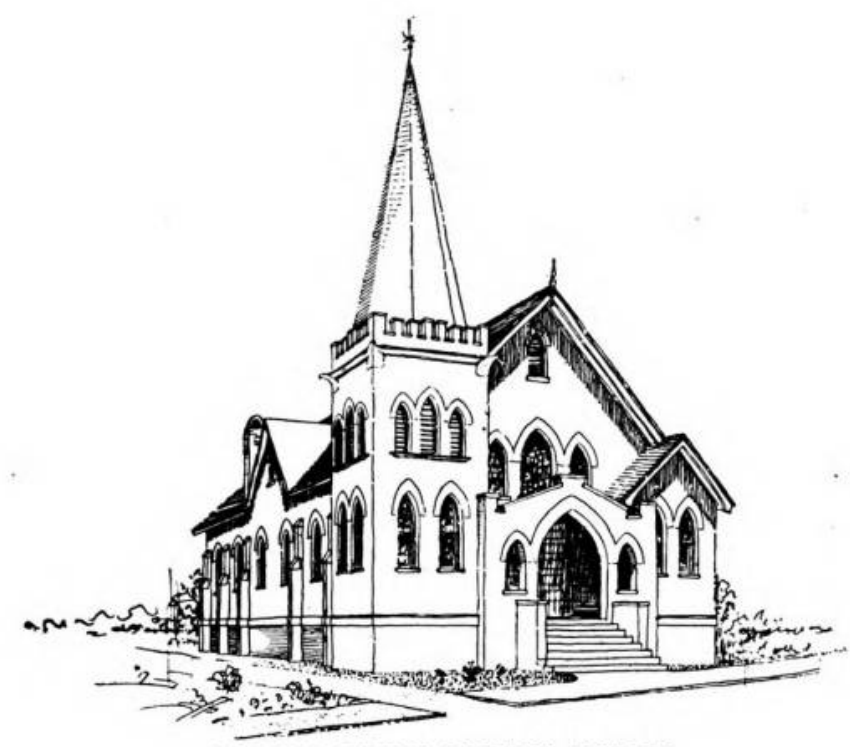

Figure 5: Jackson Avenue Baptist Church, erected by Solomon Jones in Memphis, TN.

Jones's visual depictions of properties were especially remarkable. He included in the Informer images of the church buildings he had erected such as the First Baptist in Muskogee, and, more than a decade later, in his motion pictures that also included subjects such as the National Baptist Publishing Board Headquarters in Nashville, Tennessee, the First Baptist Church of Guthrie, "erected by Dr. Jones, 1898 to 1905," Langston University, the country home of Mr. and Mrs. George W. Davis, and Lincoln High School. ${ }^{12}$ Together these images, as the earlier depictions of black properties in black print culture, presented a perspective on racial progress 
that merged mass media to the built environment in a broader conceptualization of the places of modern black life.

Jones's churches, his newspaper, and his films continued the practices of African Americans in late 19th century. Buildings and mass media were of particular importance in forging a shared conception of black place-making. They served as public sites for African Americans to come together for matters of survival, advancement, and enjoyment; and they facilitated the self-directed mobility of information and people across space. Real properties enabled the growth of black print culture, which in turn, supported the development of black claims to the post-emancipation physical landscape by publishing information about the success of black migrants in acquiring real estate, broadcasting information about land-owning opportunities, and printing images of black properties. The co-constitutive role of media and properties in the processes of black place-making negotiated a desire for permanence and stability with a recognition of the turbulence that so often lay ahead.

\section{NOTES}

The author would like to thank the anonymous referees for The Journal of African American History and, in particular, the following individuals: Leora Auslander, Kendra Field, V. P. Franklin, Andrew Grodner, Lara Kriegel, Jacob F. Lee, Amrita Myers, Holly Shissler, Christina Synder, Tara Zahra, and the participants in the Neubauer Collegium for Culture and Society's workshop, People and Things on the Move: Migration and Material Culture.

${ }^{1}$ Ida B. Wells, Southern Horrors: Lynch Law in All Its Phases (1892; reprinted Alexandria, VA, 2003).

${ }^{2}$ Ibid.; Ida B. Wells, Crusade for Justice: The Autobiography of Ida B. Wells (Chicago, IL, 1970).

${ }^{3}$ Wells, Crusade for Justice; 71, 82. "An Interview with Mr. Willis Sidney Monroe, Kingfisher, Oklahoma," interviewed by Louise S. Barnes, Willis Sidney Monroe, Works Progress Administration, 14 March 1935, 1-2.

${ }^{4}$ Place-making is a dynamic set of relational and inherently historical practices, rather than a simple set of latitudinal and longitudinal coordinates. A sense of place emerges from the "affective attachments" of socially differentiated groups as they interact with each other and the world around them. Timothy Cresswell, Place: A Short Introduction (London, 2004), 1-3; Charles W. J. Withers, "Place and the 'Spatial Turn' Geography and in History," Journal of the History of Ideas 70 (October 2009): 640; Peter Merriam and Rhys Jones, "Nations, Materialities and Affects," Progress in Human Geography (18 May 2016); Doreen Massey, "A Global Sense of Place," in Space, Place and Gender (Minneapolis, MN, 1994), 146-156; Barney Warf, Time-Space Compression: Historical Geographies (New York, 2008).

${ }^{5}$ Angel David Nieves and Leslie M. Alexander, eds., "We Shall Independent Be": African American Place Making and the Struggle to Claim Space in the United States (Boulder, CO, 2008); N. D. B. Connolly, A World More Concrete: Real Estate and the Remaking of Jim Crow South Florida (Chicago, IL, 2014); Kevin Fox Gotham, Race, Real Estate, and Uneven Development: The Kansas City Experience, 1900-2000 (Albany, NY, 2002); Kevin McGruder, Race and Real Estate: Conflict and Cooperation in Harlem, 1890-1920 (New York, 2015); Adrienne Brown and Valerie Smith, eds., Race and Real Estate (New York, 2015). A few studies that consider collective property ownership have looked at black universities and beaches. Andrew Kahrl writes about communally owned land in The Land Was Ours: African American Beaches from Jim Crow to the Sunbelt South (Cambridge, MA, 2012). For the relationship between ideas of property and kinship, see Dylan C. Penningroth, The Claims of Kinfolk: African American Property and Community in the Nineteenth-Century South (Chapel Hill, NC, 2003), 49-54.

${ }^{6}$ Alexander X. Byrd, Captives and Voyagers: Black Migrants across the Eighteenth-Century British Atlantic World (Baton Rouge, LA, 2008); Ira Berlin, The Making of African America: The Four Great Migrations (New York, 2010). Important early works include I. Garland Penn, The Afro-American Press and its Editors (Salem, NH, 
1891); George W. Gore, Jr., Negro Journalism: An Essay on the History and Present Conditions of the Negro Press (Greencastle, IN, 1922); and Frederick G. Detwiler, The Negro Press in the United States (Chicago, IL, 1922). Also see Vishnu Oak, The Negro Newspaper (Yellow Springs, OH, 1948). Though the black press did not receive considerable attention in subsequent decades, a few important studies were published, including Roland Wolseley, The Black Press, U.S.A. (Ames, IA, 1971); James S. Tinney and Justine J. Rector. Issues and Trends in Afro-American Journalism (Washington, DC, 1980); and Henry Lewis Suggs, ed., The Black Press in the South, 1865-1979 (Westport, CT, 1983). Interest in the black press was revived in the 1990s. For decades, Armistead Pride's doctoral dissertation was a seminal source for scholars of the black press. See Armistead Pride and Clint C. Wilson II, A History of the Black Press (Washington, DC, 1997). Scholars of the black press have since attended more closely to the concerns of the antebellum black press. See Frankie Hutton, The Early Black Press in America, 1827-1860 (Westport, CT, 1993); and Bernell Tripp, Origins of the Black Press: New York 1827-1847 (Northport, AL, 1992); on specific regions, see Henry Lewis Suggs, ed. The Black Press in the Middle West, 1865-1985 (Westport, CT, 1996); and Julius E. Thompson, The Black Press in Mississippi, 1865-1985 (Gainesville, FL, 1993); and on issues such as gender and black women journalists, see Jane Rhodes, Mary Ann Shadd Cary: The Black Press and Protest in the Nineteenth Century (Bloomington, IN, 1998); Rodger Streitmatter, Raising Her Voice: African-American Women Journalists Who Changed History (Lexington, NY, 1994). There are numerous studies of Ida B. Wells that examine her career as a journalist, including Mia Bay, To Tell the Truth Freely: The Life of Ida B. Wells (New York, 2010); and Paula J. Giddings, Ida B. Wells: A Sword Among Lions (New York, 2008).

${ }^{7}$ Thomas C. Holt, The Problem of Race in the Twenty-First Century (Cambridge, MA, 2000), 69.

${ }^{8}$ Byrd, Captives and Voyagers, 5-7.

${ }^{9}$ Alisea Williams McLeod, "Register of Freedmen: Camp Shiloh, Memphis, Tennessee, Circa 1863," http://lastroadtofreedom.com/documents/12.pdf.

${ }^{10}$ David M. Tucker, Black Pastors and Leaders: Memphis, 1819-1972 (Memphis, TN, 1975), 8-15.

${ }^{11}$ Gerald L. Smith, “'Duty of the House': African-American Communities in Memphis, Tennessee, 1862-1923,

“Tennessee Historical Quarterly 55 (Summer 1996): 135; Beverly G. Bond, “"Every Duty Incumbent Upon Them': African-American Women in Nineteenth Century Memphis," Tennessee Historical Quarterly 59 (Winter 2000): 260; Bobby Lovett, "Memphis Riots: White Reaction to Blacks in Memphis, May 1865-July 1866," Tennessee Historical Quarterly 38 (Spring 1979): 10.

${ }^{12}$ Chandra Manning, Troubled Refuge: Struggling for Freedom in the Civil War (New York, 2016), 153.

13“"Order by the Commander of the District of Memphis Tennessee," [17 July 1863] General Orders No. 75," in Freedom, A Documentary History of Emancipation: Series 1, Vol. 3: The Wartime Genesis of Free Labor: The Lower South, ed. Ira Berlin, Thavolia Glymph, et al. (Cambridge, UK, 1990), 714-715; McLeod, "Register of Freedmen."

14“"From Corinth, Memphis, etc.," New York Times, 30 October 1862.

${ }^{15} \mathrm{~J}$. M. Keating, History of the City of Memphis and Shelby County Tennessee (Syracuse, NY, 1888), 519, 560, 568.

${ }^{16}$ Quotes from Elizabeth A. Meriwether printed in Elizabeth A. Meriwether, Recollections of 92 Years, 1824-1916 (Nashville, TN, 1958), 164-67 quoted in Lovett, "Memphis Riots," 11.

${ }^{17}$ For examples of antebellum black codes, see: A Digest of the Ordinances of the City Council of Memphis, from the Year 1826 to 1857 (Memphis, TN, 1857), 23, 31, 48, 49, 74, 144, 177, 219.

${ }^{18 "}$ "Chapter CXXX, [March 23, 1875]," Acts of the State of Tennessee Passed at the General Assembly (Nashville, TN, 1875), 217.

${ }^{19}$ Lovett, "Memphis Riots," 13.

${ }^{20} \mathrm{~A}$. C. Long, Long's Memphis City Directory, 1865 (Memphis, TN, 1865), 45.

${ }^{21}$ Another important point is made by legal historian Laura F. Edwards, see "African Americans involved themselves in the legal system despite the fact they couldn't claim individual rights because nobody understood the political terrain only in those terms." Laura F. Edwards, "Status without Rights: African Americans and the Tangled History of Law and Governance in the Nineteenth-Century U.S. South," The American Historical Review 112 (April 2017): 368.

${ }^{22}$ Green P. Hamilton, Bright Side of Memphis: A Compendium of Information Concerning The Colored People of Memphis, Tennessee, Showing Their Achievements in Business, Industrial and Professional Life and Including Articles of General Interest on the Race (Memphis, TN, 1908), 7.

${ }^{23}$ Dayle B. DeLancey, "Vaccinating Freedom: Smallpox Prevention and the Discourses of African American Citizenship in Antebellum Philadelphia," Journal of African American History 95 (Summer-Fall 2010): 296-321.

${ }^{24}$ Ida B. Wells-Barnett, The Memphis Diary of Ida B. Wells, ed. Miriam DeCosta-Willis (Boston, MA, 1995), 26-27, 30-31. 
${ }^{25}$ It is also important to point out that black migrants claimed urban space through mortgaged, rented, occupied, and collectively owned properties. As historians such as Dylan Penningroth have shown, African Americans' definitions of private real property have historically been dictated not only by law but an array of social arrangements. Penningroth, The Claims of Kinfolk.

${ }^{26}$ Cossitt Library opened a "Negro Branch" in 1903.

${ }^{27}$ Avalanche, 18 January 1875 , p. 1

${ }^{28}$ Hamilton, Bright Side of Memphis, 84.

${ }^{29}$ For information on educational institutions initially supported by donations from whites, but then supported financially by African Americans, see V. P. Franklin and Carter Savage, eds., Cultural Capital and Black Education: African American Communities and the Funding of Black Schooling, 1865 to the Present (Greenwich, CT, 2004).

${ }^{30}$ Tucker, Black Pastors and Leaders, 8.

${ }^{31}$ Public Ledger, 27 October 1877, 3.

${ }^{32}$ In 1866, Memphis was home to eight black churches; by 1900, there were more than forty. Hamilton, Bright Side of Memphis; Lovett, "Memphis Riots": 13; http://www.memphis.edu/benhooks/mapping-civil-rights/civil-war-reconstruction.php.

${ }^{33}$ By the 1930s, African Americans had accumulated $\$ 164.5$ million dollars (or today nearly 2.8 billion dollars today) in church properties. Not included in these figures were the numerous small churches in houses and storefronts, often rented or borrowed, which most sociologists and census takers ignored. Benjamin Mays, The Negro 's Church (New York, 1933), 114. St. Clair Drake, Churches and Voluntary Associations in the Chicago Negro Community (Chicago, IL, W.P.A. District 3, 1940), 149-150. See also, St Clair Drake and Horace Cayton, Black Metropolis: A Study of Negro Life in a Northern City (Chicago, IL, 1945), 58.

${ }^{34}$ Drake and Cayton, Black Metropolis, 58-59.

${ }^{35}$ W. E. B. Du Bois, ed., The Negro Church (Atlanta, GA, 1903), 84. Gilbert Osofsky, Harlem, the Making of a Ghetto: Negro New York, 1890-1930 (Chicago, IL, 1996), 79, 115; Cara Caddoo, Envisioning Freedom: Cinema and the Building of Modern Black Life (Cambridge: MA, 2014), 18-20.

${ }^{36}$ As scholars such as W. E. B. Du Bois, V. P. Franklin, and Evelyn Higginbotham have explained, the roles of churches extended far beyond the realm of religious life. Black churches rose to meet more secular needs, especially in response to Jim Crow segregation as African Americans turned inward to their own institutions for collective racial progress. W. E. B. Du Bois, ed., The Negro Church (Atlanta, GA, 1903), 38; V. P. Franklin, Black Self-Determination: A Cultural History of African American Resistance (New York, 1992); Evelyn Brooks Higginbotham, Righteous Discontent: The Women's Movement in the Black Baptist Church, 1880-1920 (Cambridge, MA, 1993).

37"Records of the Assistant Commissioner for the State of Tennessee, Bureau of Refugees, Freedmen, and Abandoned Lands, 1865-1869," National Archives Microfilm Publication M999, Roll 34, "Reports of Outrages, Riots and Murders, Jan. 15, 1866-Aug. 12, 1868," Affidavits regarding the 1866 Memphis Riot.

${ }^{38}$ Memphis Riots and Massacres, Select Committee on the Memphis Riots, 39th Congress, House of Representatives Report, 1st Session. No. 101, 25 July 1866, 13-16.

39،"The Memphis Riots," Harper's Weekly, 26 May 1866, 321.

${ }^{40}$ Hannah Rosen, Terror in the Heart of Freedom: Citizenship, Sexual Violence, and the Meaning of Race in the Postemancipation South (Chapel Hill, NC, 2009).

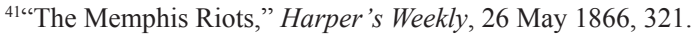

${ }^{42}$ Wilbert L. Jenkins, Climbing Up to Glory - A Short History of African Americans During the Civil War (Wilmington, DE, 2002), 194. Freedman's Savings and Trust Company, Memphis Branch, account no. 115, 19 October 1866. "Record for Morris Henderson," 15 February 1866, Freedman Savings and Trust Company Records, NARA. The 1874 Freedman's Bank failure slowed the church's construction.

${ }^{43}$ Thomas O. Fuller, History of the Negro Baptists of Tennessee (Memphis, TN, 1936), 64. Tucker, Black Pastors and Leaders, 9. Richard H. Hulan, Robert C. Giebner, "First Baptist Church, 379 Beale Street, Memphis, Shelby County Tennessee, Historic American Buildings Survey National Park Service Department of the Interior Washington, D.C.," ed., Susan McCown, HABS No. TN-181 (1972; 1985), 3.

44"'Trustees of the Beale St. Baptist Church and their Successors," Deed, Shelby County Register of Deeds: Book 0263, 17 May 1889, 452.

${ }^{45}$ Fuller, History of the Negro Baptists of Tennessee, 54, 74.

${ }^{46}$ Tucker, Black Pastors and Leaders, 11.

${ }^{47}$ American Baptist Year-Book, 1873 (Philadelphia, PA, 1873); George P. Rowell and Co., American Newspaper Directory (New York, 1873), 204. 
${ }^{48}$ Rowell and Co., American Newspaper Directory, 204. In 1877, the owner and business manager of the Memphis Planet was Alfred Froman, Jr. George P. Rowell \& Co.'s American Newspaper Directory (New York, 1877$), 405$. Paula J. Giddings, Ida B. Wells, 60-81; Linda O. McMurry, To Keep the Waters Troubled: The Life of Ida B. Wells (Oxford, UK 2000). Penn, The Afro-American Press, 270; Directory of the Taxing District of Memphis, Shelby County, Tenn. 1883 (Memphis, TN, 1883).

49،"The Freedmen's Bureau Report on the Memphis Race Riots of 1866, T. W. Gilbreth, Memphis, TN, to Maj. Genl. O. O. Howard \& Commissioner B. R. F. \& A. L.” (Washington DC, 22 May 1866).

${ }^{50}$ Richard H. Abbott, For Free Press and Equal Rights: Republican Newspapers in the Reconstruction South (Athens, GA, 2004), 80-81.

${ }^{51}$ Tucker, Black Pastors and Leaders, 61.

${ }^{52}$ J. H. Grant, Defense of the Negro: A Review of the Commercial Appeal's Attack on the Negro (Memphis, TN, 1903).

${ }^{53}$ Rowell and Co., American Newspaper Directory (1873).

${ }^{54}$ Ibid., 204.

${ }^{55}$ Armistead Pride and Clint C. Wilson II, A History of the Black Press (Washington DC, 1997), 131.

${ }^{56} \mathrm{C}$. R. Wetherbe, Directory of the Taxing District of Memphis, Shelby Co., Tenn. 1883, Vol. X (Memphis, TN, 1883), 10.

${ }^{57}$ Preston Lauterbach, Beale Street Dynasty: Sex, Song, and the Struggle for the Soul of Memphis (New York, 2015).

${ }^{58}$ Hamilton, Bright Side of Memphis, 237.

${ }^{59}$ Ibid., 238.

${ }^{60}$ Ibid.

${ }^{61}$ Giddings, Ida B. Wells.

${ }^{62}$ Lauterbach, Beale Street Dynasty.

63"History," http://www.loc.edu/about-loc/history.asp

${ }^{64}$ Hamilton, Bright Side of Memphis, 237.

${ }^{65}$ Ibid., 238.

${ }^{66}$ Drake and Cayton, Black Metropolis, 628.

${ }^{67}$ Rowell and Co., American Newspaper Directory (1873); George P. Rowell \& Co. 's American Newspaper Directory (New York, 1877); George P. Rowell \& Co. 's American Newspaper Directory (New York, 1884); George P. Rowell \& Co.'s American Newspaper Directory (New York, 1897), American Baptist Year-Book 1873; Directory of the Taxing District of Memphis (Shelby County, TN, 1883).

68"General News in Brief: Items Gathered from All Parts of the Country" (Harrisburg, Pennsylvania) State Journal, 19 July 1884, 1; "News and Sentiment (From Colored Exchanges)," Huntsville [AL] Gazette (Huntsville, Alabama), 26 July 1884, 3. History of Shelby County (Nashville, TN, 1887), 904-916.

${ }^{69}$ Countee published the paper with William A. Brinkley, pastor of the Washington Street Baptist Church with support from the Tennessee Baptist Convention. Wells, Crusade for Justice, 43. History of Shelby County, 908.; Rowell's American Newspaper Directory (1873, 1877).

${ }^{70}$ History of Shelby County, 908.

${ }^{71}$ Wells, Crusade for Justice, 43-44. Wells-Barnett, The Memphis Diary.

${ }^{72}$ Wells-Barnett, The Memphis Diary; George Batten, Directory of the Religious Press of the United States (New York, 1892).

73،"Literacy from 1870 to 1979," Excerpts from Chapter 1 of 120 Years of American Education: A Statistical Portrait, ed. Tom Snyder (online, 1993), https://nces.ed.gov/naal/lit_history.asp.

${ }^{74}$ Before the Chicago Defender, there are relatively few records of newsboys for the black press, Some papers were also delivered door to door. As a child, Anita Reynolds delivered newspapers door to door, probably the Baltimore Afro-American. Anita Reynolds, ed., American Cocktail, Howard M. Miller (Cambridge, MA, 2014$), 77$.

${ }^{75}$ Wells, Crusade for Justice, 55.

${ }^{76}$ Ibid., chapter 5.

${ }^{77}$ Ibid., 59.

${ }^{78}$ Ibid.

${ }^{79}$ Ibid., 61.

${ }^{80}$ Ibid., 43.

${ }^{81}$ Ibid.

${ }^{82}$ Penn, Afro-American Press, 235, 302, 306. 
${ }^{83}$ Anne Elizabeth Carroll, Word, Image, and the New Negro (Bloomington, IN, 2005); Jasmine Nicole Cobb, Picture Freedom: Remaking Black Visuality in the Early Nineteenth Century (New York, 2015); Henry Louis Gates, Jr., "The Trope of a New Negro and the Reconstruction of the Image of the Black," Representations 24 (Autumn 1988): 129-155; Shawn Michelle Smith, Photography on the Color Line: W. E. B. Du Bois, Race, and Visual Culture (Durham, NC, 2004), Deborah Willis and Barbara Krauthamer, Envisioning Emancipation: Black Americans and the End of Slavery (Philadelphia, PA, 2013).

${ }^{84} \mathrm{Few}$ black newspapers from turn-of-the-century Memphis still exist.

${ }^{85}$ Hamilton, Bright Side of Memphis, 94, 134, 158, 223, 250-252, 266, 279, 292, 294.

${ }^{86}$ Wells, Crusade for Justice.

${ }^{87}$ New York Freeman, 16 Oct 1886, 2.

${ }^{88}$ Washington Bee, 12 March 1887, 2

${ }^{89}$ Most newspapers only survived only a few years. Their quick turnover should not be used to measure their "success." In her history of religious periodicals, Candy Gunther Brown explained that both trade and religious papers in the 19th century newspapers lasted on average for only about two to four years. Candy Gunther Brown, The Word in the World: Evangelical Writing, Publishing, and Reading in America, 1789-1880 (Durham, NC, 2004), 154.

${ }^{90}$ Huntsville Gazette, 4 August 1888, 3.

${ }^{91}$ Testimony of David Ferguson, "Featherson vs. Cate," in Digest of Contested-Election Cases in the Fifty-First Congress, Chester H. Rowell, ed. (Washington, DC, 1891), 80.

${ }^{92}$ Huntsville Gazette, 4 August 1888, 3; "Featherson v. Cate," Digest of Contested-Election Cases in the Fifty-First Congress, 77-146.

93“"Featherson v. Cate," 81-82.

${ }^{94}$ See chapter 7 in Lauterbach, Beale Street Dynasty.

${ }^{95}$ The Laborer was a black newspaper first published in 1886; I. Garland, Penn, The Afro-American Press (Springfield, MA, 1891), 112.

${ }^{96}$ Robert S. Levine, "Circulating the Nation: David Walker, the Missouri Compromise and the Rise of the Black Press," in The Black Press: New Literary and Historical Essays, ed. Todd Vogel (New Brunswick, NJ, 2001), $17-24$.

${ }^{97}$ Penn, The Afro-American Press, 431.

${ }^{98}$ Ibid., 432.

${ }^{99}$ Ibid., 440.

${ }^{100}$ Penn, The Afro-American Press; James T. Haley, Afro-American Encyclopaedia, or, The Thoughts, Doings, and Sayings of the Race (Nashville, TN, 1895). Religious texts included Baptist Catechism and Doctrine (1899), Daniel A. Payne's History of the African Methodist Episcopal Church, ed. C. S. Smith (1891); and E.K. Love's History of the First African Baptist Church (1888); and James Meriles Simms's The First Colored Baptist Church in North America (1888).

${ }^{101}$ Richard H. Boyd's books included: National Baptist Pastor's Guide (1900), The Separate or "Jim Crow" Car Laws (1909), and The Story of the Publishing Board (1920). Bobby L. Lovett, “A Black Man's Dream: The First 100 Years: Richard Henry Boyd and the National Baptist Publishing Board,” Ph.D. diss., University of Arkansas, 1993.

${ }^{102}$ Wells, Crusade for Justice, 81.

${ }^{103}$ Ibid., $73,75$.

${ }^{104}$ Ibid., 91.

${ }^{105}$ Ibid., 54; Henry Davenport Northrop, Joseph R. Gay, and I. Garland Penn, The College of Life; or, Practical Self-Educator: A Manual of Self-Improvement of the Colored Race (Chicago, IL, 1895), 100; Wells, Memphis Diaries.

${ }^{106}$ Wells, Crusade for Justice, 87.

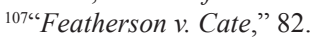

${ }^{108}$ Wells, Crusade for Justice, 91-2.

${ }^{109}$ Who's Who among the Colored Baptists of the United States described his accomplishments in constructing the "largest and wealthiest Baptist church in the State of Oklahoma," The First Baptist Church of Muskogee with an "edifice [that] cost in the aggregate $\$ 23,000$ " and a $\$ 5,000$ parsonage." Samuel William Bacote, Who's Who among the Colored Baptists of the United States (Kansas City, MO, 1913).

${ }^{110}$ N. W. Ayer \& Son's American Newspaper Annual and Directory (Philadelphia, PA, 1910); and Ayer Directory, Newspapers, Magazines, and Trade Publications (Philadelphia, PA, 1921), 801. 
${ }^{11}$ Wagoner, OK, Baptist Informer, 21 July 1910, 5; Baptist Informer, 23 September 1910, 1 \& 5 (publication date is as best as I can decipher; a word on page 1 is illegible). All issues from the Oklahoma Historical Society. ${ }^{112}$ Baptist Informer, 26 May 1910; and 5 October 1910.

This content downloaded from 129.079.038.063 on June 04, 2019 07:28:16 AM All use subject to University of Chicago Press Terms and Conditions (http://www.journals.uchicago.edu/t-and-c). 